
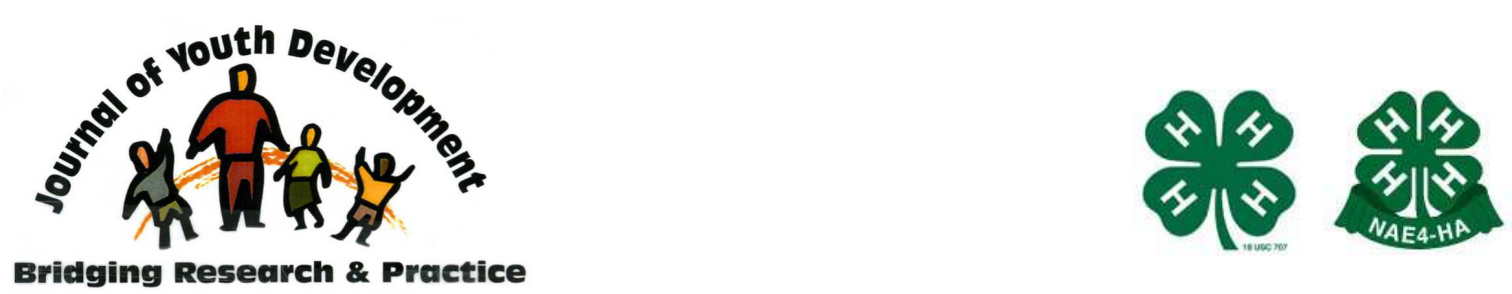

\title{
A National Professional Development System for Youth Workers
}

\author{
Barbara Stone, Ph.D. \\ National 4-H Headquarters \\ Families 4-H and Nutrition \\ Cooperative State Research, Education, and Extension Service, USDA \\ Washington, DC \\ bstone@csrees.usda.gov \\ Pam Garza \\ National Youth Development Learning Network \\ National Collaboration for Youth/National Human Services Assembly \\ Washington, DC \\ pam@nassembly.org \\ Lynne Borden, Ph.D. \\ University of Arizona \\ Tucson, AZ \\ bordenl@ag.arizona.edu
}




\title{
JOURNAL OF YOUTH DEVELOPMENT \\ bridging research and practice

\section{A National Professional Development System for Youth Workers}

\author{
Barbara Stone \\ Cooperative State Research, Education, and Extension Service, USDA \\ Pam Garza \\ National Collaboration for Youth/National Human Services Assembly \\ Lynne Borden \\ University of Arizona
}

\begin{abstract}
A persistent challenge in the youth development field is the lack of a systemic approach to attracting, developing and sustaining its workforce, particularly direct service workers. While serious efforts to address workforce development have dotted the youth work landscape, especially over the last 15 years, much of this progress has been organization-specific rather than across the field or systemic (Quinn, 2004). In 2004, 30 individuals who were knowledgeable about the issues came together to address the challenge of attracting, developing and retaining youth workers. They represented diverse sectors of the field, including direct service workers, national youthserving agencies, local and national intermediary organizations, federal agencies and corporate and foundation philanthropies. They took the bold step of designing an initial framework and strategy for a coordinated national professional development system for youth workers. They also agreed to pursue the next steps to collectively create the system (Stone, Garza, \& Borden, 2005).
\end{abstract}

\section{Introduction}

Like most organizations across the United States, youth organizations require highly skilled, knowledgeable workers. The view that anyone can do youth work is both mistaken and dismissive. In fact, a youth worker must be equipped with a broad range of knowledge, skills, and behaviors and apply them in a variety of settings when working with young people. 
As a career, youth work can be both exhilarating and exhausting. Keeping the most talented youth workers in the field is critical to building the status, viability and effectiveness of the youth development profession. Yet there is little information available about the factors that attract and keep youth workers.

\section{Making the Case}

Many youth organizations with limited assets continue to strive to develop and retain a highquality workforce. Despite best intentions, a landmark report produced by the Annie E. Casey Foundation (2003), has documented heavy workloads, long hours, high vulnerability to burnout, and high turnover among employees of youth development organizations. Additionally, there remains a wide range of workforce issues (Stone, Garza, \& Borden, 2005):

- Low wages and inadequate benefits for workers

- Poor image of youth work and undervalued as a profession

- Scarcity of intentional career paths

- General disinterest and limited knowledge in nonprofit sector careers

- Lack of assessment data on youth worker needs

- Limited evaluation of the impacts of learning and professional development

- Limited interest in professional development by foundations

In interviews conducted by the University of Arizona, professional development was cited as a key factor in attracting and keeping a talented workforce in the field of youth work. The interviews also reinforced the continuing demand for an effective mix of in-service and training opportunities, formal and informal mentoring, and networking (Stone, Garza \& Borden, 2005).

A critical link has also been established between youth outcomes and positive relationships with skilled staff. A Harvard Family Research Project report has documented evidence of the impact of professional development activities for out-of-school time workers on at least two levels: staff development can affect youth outcomes as well as impact the sustainability of the youth development work force (Bouffard \& Little, 2004).

While progress is being made in addressing these issues, current efforts to address the professional development of youth workers are fragmented and often organization-specific. A greater focus is needed to collectively attract, develop and keep youth workers for the next generation.

\section{Wingspread Conference}

In November, 2004, a landmark event, a Wingspread conference on Attracting, Developing and Retaining Youth Workers for the Next Generation, was held at the Wingspread Conference Center in Racine, Wisconsin. The purpose of the conference was to engage key entities from a range of organizations in creating a collaborative, comprehensive strategy to attract, develop and keep youth workers within the field of youth development.

The conference built on the knowledge of past efforts to support professional development in youth-serving organizations. A scan of the literature and a review of existing documents and practices determined the initial direction of the conference. Research conducted through interviews and the subsequent analysis and recommendations by thought leaders, also shaped the design of the conference. 
The Wingspread Conference was catalytic in that it brought together the leadership, expertise, and diverse voices from across the field to collectively address the continuing challenges in attracting and keeping youth workers in the field. The diversity of the participants was an important aspect of the conference: representatives came from national, state, and local youth development organizations and intermediaries, colleges and universities, and funding organizations. The differing experiences, priorities and perspectives brought strength and clarity to the work. The voices included youth workers, who offered a community, ground-level viewpoint. Growing from those local needs, the group was able to surpass individual organizational boundaries for the benefit of the field.

\section{Building a Professional Development System}

Participants began their work by establishing a shared definition of "youth worker".

"A youth worker is an individual who works with or on behalf of youth to facilitate their personal, social, and educational development and enable them to gain a voice, influence, and place in society as they make the transition from dependence to independence."

Next, the participants used their experience, knowledge and expertise to identify key components of a coordinated system that would increase the likelihood of attracting, developing and retaining youth workers.

\section{Components of the System}

Standards and Competencies. Agreement on the knowledge, skills, and attitudes needed in youth work at various levels of the system. The focus on standards was not intended to create something new, but to agree on consistent standards for professional development and leverage competency models that exist within and across organizations.

Key Recommendation. By 2008, a set of widely adopted core competencies and performance indicators align and unify youth development professionals in practice (direct service), programs (organization/program development), and policy (strategic and systems development).

Training and Delivery System. Aggressive development of a learning system that attracts, develops and sustains youth workers. The focus of this component involves expanding existing efforts, increasing coordination and enlarging peer networks. Key aspects of the system would include pre-service; higher education training; in-service training, apprenticeship experiences, and training offered by the organization or local or national intermediary.

Key Recommendation. Develop a learning system that is cohesive, policy-driven, and credential based providing multiple pathways to demonstrate competency as evidenced by portfolios and other assessments.

Career Ladders and Compensation Guidelines. Explicit mechanisms for attracting workers to the field and for ensuring fair and adequate pay along the continuum of their careers. Career paths and compensation are essential to building a professional development system and should be inextricably linked to the other components. Mechanisms should be in place to ensure that youth workers receive increased compensation for demonstrating agreed-upon competencies and participating in professional development that improves performance. Key Recommendation. Conduct a study that defines the current state of: career ladders; compensation (wages and benefits; environments and working conditions); entry and exit from 
and mobility within the field; recruitment and retention; and demographics: who comes, who stays and who leaves the field.

Evaluation. The creation of basic evaluation approaches that address key questions, including whether and how professional development improves practice and whether and how improved practice leads to improved youth outcomes. Evaluation and research should be integrated into and guide the development of the professional development system, and that assesses its progress and effectiveness.

Key Recommendation. Develop and launch a proactive research agenda that is integrated into and guides the transformation of the professional development system and that assesses progress and effectiveness.

\section{System Processes}

In order to accomplish the recommendations, there are a series of processes that must take place around each component: knowledge development; consensus development; adoption, and; strategic communication and support.

Knowledge Development: Overwhelmingly, participants agreed that there is a critical need to gather and synthesize existing research that would address the four components of a national professional development system.

Consensus Development: Group members calculated it may take 10 -15 years to build a high quality and enduring professional development system for youth workers. Throughout this time, it will be critical to involve representatives from the many sectors of the field to elicit their input and their feedback on the system components.

Adoption: A national professional development system - once implemented - will only be as strong as its impact on youth workers and on their daily work. For an effective system to be fully embraced by youth workers, it will require explicit support mechanisms at all levels national, regional, state, and especially local.

Strategic Communication and Support: Strategic communication with both internal and external audiences in order to build momentum and gain support is necessary for the success of a national professional development system.

\section{Summary}

The system envisioned at the Wingspread Conference included consistent standards and competencies for youth workers, quality training and education, an effective learning delivery system, intentional and varied career paths, guidelines for compensation, and effective use of research and evaluation. At its best, the Wingspread Conference confronted the key factors that create barriers to attracting, developing, and keeping youth workers, especially the fragmentation of current efforts. The conference resulted in system-wide strategies that will advance the work of building a comprehensive national professional development system for youth workers.

The remarkable work done prior to the Wingspread Conference and addressed collectively at the Conference, offers an opportunity for anyone that works with and on behalf of young people to join in the building of a national professional development system. Now named the Next Generation Youth Work Coalition, attention will be given to the interrelated areas of knowledge development, consensus, adoption and strategic communications and support. By 
approaching the work of professional development from a systems approach, there will be focused energy and support from across the field, increased respect and visibility for youth work, and greater confidence in the ability of youth workers to make a positive difference in the lives of young people.

For more information about ongoing work from the Wingspread Conference, or to become involved in the Next Generation Youth Work Coalition contact Pam Garza at pam@nassembly.org.

\section{References}

Annie E. Casey Foundation. (2003). The Unsolved Challenge of System Reform: The Condition of the Frontline Human Services Workforce. Available online at:

http://www.aecf.org/initiatives/hswi/report rev.pdf

Bouffard, S., \& Little, P. (2004). Promoting Quality through Professional Development. Issues and Opportunities in Out-of-School time Evaluation. Harvard Family Research Project, August.

Quinn, J. (2004). Winter, pp 13-24 in Professional Development in the Youth Development Field: Issues, Trends, Opportunities and Challenges. Professional Development for Youth Workers, New Directions for Youth Development, Garza, P., Borden, L., Astroth, K., Eds. San Francisco: Jossey Bass.

Stone, B., Garza, P., \& Borden, L. (2005). Wingspread Conference Proceedings, Attracting, Developing and Retaining Youth Workers for the Next Generation. Available online at: www.nassembly.org

(C) Copyright of Journal of Youth Development Bridging Research and Practice. Content may not be copied or emailed to multiple sites or posted to a listserv without copyright holder's express written permission. Contact Editor at: patricia.dawson@oregonstate.edu for details. However, users may print, download or email articles for individual use.

ISSN 2325-4009 (Print); ISSN 2325-4017 (Online) 